\title{
表观遗传与肿瘤代谢研究进展
}

\author{
韩恒毅, 冯 帆, 李海涛 \\ 清华大学医学院, 北京 100084
}

[ 摘 要] 表观遗传学主要关注 DNA 甲基化、组蛋白修饰、染色质重塑, 以及非 编码 RNA 等超越 DNA 序列的基因调控机制。表观遗传机制参与了个体发育、细 胞命运决定和肿瘤发生等众多生物学过程。其中表观遗传信息以各种染色质修饰 和高级结构的形式存储于基因组中, 它的建立和维持与细胞代谢紧密相关。肿瘤 细胞中存在的代谢改变包括有氧糖酵解、葡萄糖摄取量增加、谷氨酰胺代谢异常 活跃、利用非主要供能物质供能等,这些改变满足了肿瘤发生发展过程中旺盛的 能量和物质需求, 帮助细胞适应缺氧的肿瘤微环境, 进而为肿瘤增殖、侵袭、迁移 等生物活动提供支持。肿瘤细胞的表观遗传修饰与代谢之间存在复杂的相互关 系, 一方面肿瘤细胞中的代谢产物作为表观修饰酶的辅因子、修饰供体或拮抗分 子影响表观修饰景观; 另一方面表观遗传修饰可以直接改变代谢酶和转运蛋白的 表达或通过影响信号转导和转录因子的表达调控细胞代谢。本文综述了不同表观 遗传学过程与肿瘤细胞代谢之间的相互作用, 并展望两者在肿瘤治疗中的潜在应 用前景。

[关键词] 表观遗传学; 代谢; 肿瘤; DNA 甲基化; 组蛋白修饰; 非编码 RNA; 表观景 观; 综述

[中图分类号 ] R730.23 [文献标志码 ] A

\section{Research advances on epigenetics and cancer metabolism}

HAN Hengyi, FENG Fan, LI Haitao(School of Medicine, Tsinghua University, Beijing 100084, China )

Corresponding author:LI Haitao,E-mail:Lht@tsinghua.edu.cn,https://orcid.org/00000001-6741-293X

[Abstract ] Epigenetics concerns gene regulatory mechanisms beyond DNA sequence, such as DNA methylation, histone modification, chromatin remodeling, and non-coding RNA. Epigenetic mechanisms play a key role in development,cell fate decision and

\footnotetext{
收稿日期: 2021-01-12 接受日期:2021-02-20

基金项目: 国家重点研发计划(2020YFA0803300)

第一作者: 韩恒毅, 博士研究生, 主要从事表观遗传和肿瘤生物学研究;E-mail : hanhy17@mails. tsinghua. edu. cn; https:// orcid. org/0000-0003-4840-4293. 冯 帆, 博士后, 主要从事表观遗传调控的分子机制研究; E-mail : fengfan8@mails. tsinghua. edu. cn; https://orcid. org/0000-0001-8345-2894

通信作者: 李海涛,教授,博士生导师, 主要从事表观遗传和肿瘤生物学研究;E-mail:lht@tsinghua. edu. cn; https://orcid. org/0000-0001-6741-293X
} 
tumorigenesis. Chromatin modifications and its high order structure across our genome are major forms of epigenetic information, and its establishment and maintenance are closely related to cell metabolism. Metabolic changes in cancer cells include aerobic glycolysis, increased glucose uptake, abnormally active glutamine metabolism, and the use of non-conventional energy supply. These changes meet the vigorous energy and matter needs for the development and spread of cancer, and help tumor cells adapt to hypoxia microenvironment for their survival, proliferation, invasion and migration. There is a complex relationship between epigenetic modifications and cell metabolism in tumor. On the one hand, metabolites in tumor cells may act as cofactors, modification donors or antagonists of epigenetic enzymes, thus modulating the epigenetic landscape. On the other hand, epigenetic modifications can directly regulate the expression of metabolic enzymes, transporters, signaling pathway and transcription factors to affect cell metabolism. This article reviews the crosstalk between epigenetics and cancer metabolism, to explore their potential future applications in the treatment of tumors.

[Key words] Epigenetics; Metabolism; Tumor; DNA methylation; Histone modification; Non-coding RNA; Epigenetic landscape; Review

[ J Zhejiang Univ (Med Sci), 2021, 50(1): 1-16. ]

[缩略语] 信使 RNA(messenger RNA, mRNA); 长链非编码 RNA(long non-coding RNA, lncRNA); 环状 RNA(circular RNA, circRNA); 微 RNA(micro RNA, miRNA, miR)；S-腺苷甲硫氨酸(S-adenosyl methionine, SAM); S-腺苷-L-高半胱氨酸 (S-adenosyl-L-homocysteine, SAH); 烟酰胺腺嘌呤二核苷酸(nicotinamide adenine dinucleotide, $\mathrm{NAD}^{+}$); DNA 甲基化转移酶(DNA methyltransferase, DNMT); 腺苷三磷酸 (adenosine triphosphate, ATP)；10/11 易位蛋白家族(ten-eleven translocation family protein,TET); M2 型丙酮酸激酶(pyruvate kinase subtype M2, PKM2); 葡萄糖转运蛋白 (glucose transporter, GLUT); 果糖-1, 6-二磷酸酶 (fructose-1, 6-diphosphate,FBP); 磷脂酰肌醇 3-激 酶 (phosphoinositide 3-kinase,PI3K); 蛋白激酶 B (protein kinase B, AKT); 哺乳动物雷 帕霉素靶蛋白 (mammalian target of rapamycin,mTOR); 缺氧诱导因子 $1 \alpha$ (hypoxia inducible factor- $1 \alpha, \mathrm{HIF}-1 \alpha$ )；10 号染色体缺失磷酸酶及张力蛋白同源物 (phosphatase and tensin homolog deleted on chromosome ten,PTEN); 希佩尔林道抑癌基因 (Von Hippel-Lindau tumor suppressor, VHL); 肝激酶 B(liver kinase B, LKB); 腺苷一磷酸 (adenosine monophosphate,AMP); AMP活化蛋白激酶(AMP-activated protein kinase, AMPK); 腺苷二磷酸 (adenosine diphosphate, ADP); 组蛋白赖氨酸甲基转移酶 (histone lysine methyltransferase,HKMT); 沉默信息调节因子(silent information regulator, SIRT); 神经前体细胞表达发育下调蛋白 (neural precursor cell expressed developmentally down-regulated protein, NEDD); 环磷酸腺苷反应元件结合蛋白的结合蛋白 (CREB binding protein, CBP); 蛋白质精氨酸甲基转移酶(protein arginine methyltransferase,PRMT); 混合系白血病 (mixed lineage leukemia, MLL); 赖氨酸特异性蛋白质去 甲基化酶家族(lysine-specific protein demethylases, LSD); ATP-柠檬酸裂合酶(ATPcitrate lyase, ACL); 组蛋白脱乙酰酶 (histone deacetylase, HDAC); G 蛋白转导蛋白亚 单位家族(guanine nucleotide binding protein alpha transducing activity polypeptide family, GNAT); 短链家族酰基化辅酶 A 合成酶(acyl-CoA synthetase short chain family 
member, ACSS)；6-甲基腺嘌呤(6-methyladenosine, m6A); 甲基转移酶(methyltransferase-like, METTL); 肥胖相关基因 (fat mass and obesity associated,FTO); Alk B 同源蛋 白 (Alk B homologue, ALKBH); 酰基辅酶 A 合成酶长链家族成员 (acyl-CoA synthetase long chain family member, ACSL); 胆囊癌相关的丙酮酸羧化酶抑制剂 (gall bladder cancer associated suppressor of pyruvate carboxylase lncRNA, GCASPC)

肿瘤代谢是近年来肿瘤生物学研究的热点之 一, 肿瘤细胞中受调控的代谢改变包括有氧糖酵 解 (瓦博格效应 $)^{[1]}$ 、葡萄糖摄取量增加、谷氨酰胺 代谢异常活跃 ${ }^{[2]}$ 、利用非主要供能物质供能等, 这 些改变满足了肿瘤细胞快速增殖时旺盛的能量和 物质需求, 帮助细胞适应缺氧的肿瘤微环境, 进而 为肿瘤的增殖、侵袭、迁移等生物活动提供能量和 物质支持。代谢改变在不同组织来源的肿瘤以及 肿瘤发生发展的不同阶段广泛存在,实验证据表 明多种机制参与了肿瘤代谢的驱动和调控, 如肿 瘤微环境、癌基因、代谢酶等 ${ }^{[3]}$ 。

表观遗传是不改变基因的 DNA 序列而调控 基因表达的可遗传或可继承机制的统称,包 括 DNA 甲基化、组蛋白修饰、染色质重塑、非编 码 RNA 等 ${ }^{[4]}$ 。表观遗传参与调控细胞分化、个体 发育、肿瘤发生和发展等众多生物学过程, 是一种 将环境压力和基因表达联系起来的重要机制 ${ }^{[5]}$ 。 肿瘤细胞中普遍存在着多种以染色质修饰等为内 容的表观遗传景观变化, 如基因组水平 DNA 低甲 基化 ${ }^{[6]}$ 、H4K16 乙酰化水平显著降低等组蛋白修 饰异常 ${ }^{[7]}$ 。同时, 作为广义的表观调控机制, mRNA 甲基化修饰异常以及lncRNA、circRNA、 miRNA 等非编码 RNA 异常表达等也促进了肿瘤 的发生。

肿瘤的表观遗传与代谢之间有着复杂的相互 关系,一方面肿瘤细胞中代谢小分子常常作为表 观修饰酶的辅因子、修饰供体、激动或拮抗分子而 影响表观修饰酶的活性, 如 SAM/SAH 比值可以影 响甲基转移酶的活性进而调控 DNA 和组蛋白的 甲基化 ${ }^{[8]}$, 乙酰辅酶 $\mathrm{A}$ 和 $\mathrm{NAD}^{+}$影响组蛋白乙酰 化 ${ }^{[9-10]}$ 等; 另一方面表观遗传修饰可以直接改变 代谢酶、转运蛋白、信号转导、转录因子等的表达 来调控细胞代谢。本文主要讨论不同表观遗传学 过程影响和调控肿瘤代谢的机制,包括 DNA 甲基 化、组蛋白修饰、mRNA 修饰和非编码 RNA 等, 并 总结和展望针对肿瘤代谢的表观遗传学手段在肿 瘤治疗中的实践与前景。

\section{DNA 甲基化与肿瘤代谢}

在基因组 DNA 中存在着 5'碳原子甲基化修 饰的 5-甲基胞嘧啶残基,这种由DNMT催化的共价 修饰被称为 DNA 甲基化。在哺乳动物细胞的基 因组中, $\mathrm{CpG}$ 序列出现的频率相比其他二核苷酸 序列低, 然而在基因的 $5^{\prime}$ 端启动子附近存在着长 度约为 $1 \mathrm{~kb}$ 的 $\mathrm{CpG}$ 序列富集的区域,被称为 $\mathrm{CpG}$ 岛 ${ }^{[11]}$ 。 $\mathrm{CpG}$ 岛上的 DNA 甲基化常导致基因沉默， 而这种甲基化状态可在 DNA 复制时由DNMT 传递 到新合成的 DNA 单链,进而完成世代间的遗 传 ${ }^{[12]}$ 。DNMT 的三种亚型 DNMT1、DNMT3A和 DNMT3B 均在肿瘤中过表达 ${ }^{[13]}$ 。

SAM 是 DNMT 常见的活化甲基供体,而其去 甲基后生成的 SAH 可以抑制 DNMT 活性,故细胞 内的DNA甲基化水平受SAM/SAH比值调控。SAM 是一碳代谢循环的产物, 由甲硫氨酸和 ATP在甲 硫氨酸腺苷基转移酶催化下合成 ${ }^{[8]}$ 。证据表明, 肿瘤细胞可以通过增强一碳代谢来提高 SAM 的供 应, 如通过大型中性氨基酸转运蛋白 $1 / 4$ 的过表 达直接增加甲硫氨酸的摄取 ${ }^{[14]}$, 而SAM 的过量供 应可能会导致 CpG 位点的 DNA 超甲基化和异常 的基因沉默,并与肿瘤发生相关。研究显示, 小鼠 $G N M T$ 基因敲除使肝脏 $\mathrm{SAM}$ 升高 40 倍以上, 抑癌 基因 $R A S S F 1$ 和 $S O C S 2$ 的启动子甲基化水平升高， 肝细胞癌的发病率随之上升 ${ }^{[15]}$ 。

与 DNA 甲基化相对的是 DNA 去甲基化,两 种过程的动态平衡决定了 DNA 甲基化水平。5-甲 基胞嘧啶的去甲基过程可分为两步,分别由 TET 和胸腺嘧啶 DNA 糖苷酶催化 ${ }^{[16-17]}$ 。TET 是潜在 的肿瘤抑制因子, 其在多种人类肿瘤中表达下 调 ${ }^{[18-19]}$, 故肿瘤细胞启动子区域高甲基化可能是 由甲基化作用增强和去甲基化作用减弱协同调控 的。TET 是 $\alpha$ 酮戍二酸依赖性双加氧酶,需要 $\alpha$ 酮戊二酸作为辅因子, 并被三羧酸循环中间产物 竞争性抑制。代谢酶基因如异柠檬酸脱氢酶 1/2、 琥珀酸脱氢酶、延胡索酸酶发生突变的癌细胞可 
能会积累过量的三羧酸循环中间产物, 如 2-差基 戈二酸酯、琥珀酸酯和延胡索酸酯以抑制 TET 的 活性,进而通过影响 DNA 甲基化修饰调控肿瘤的 发生和发展 ${ }^{[20]}$ 。

由于上述 DNA 甲基化和 DNA 去甲基化过程 的异常, 相较于癌旁组织, 肿瘤细胞中普遍存在着 全基因组范围的 DNA 甲基化水平下降以及部分 基因和 miRNA 的 $\mathrm{CpG}$ 岛甲基化水平上升 ${ }^{[21]}$, 可直 接调节代谢相关基因的表达, 或通过相关信号通 路和转录因子间接调控肿瘤代谢过程。

研究发现,基因组 DNA 低甲基化状态使得多 种肿瘤中的 PKM2 表达上调 ${ }^{[22]}$ 。在糖酵解中, 其 限速酶 PKM2 可催化磷酸烯醇式丙酮酸生成丙酮 酸。PKM2 以四聚体、二聚体和单体三种不同形式 稳定存在, 而 PKM2 的四种同工酶通常以四聚体 的形式存在。PKM2 单体酶活性低, 且可定位于细 胞核, 这与瓦博格效应的产生和维持密切相 关 $^{[23]}$ 。在动物肿瘤模型和多种人类肿瘤样本中 都有癌基因低甲基化现象, 如肝细胞癌 $C-M Y C$ 基 因第三外显子低甲基化 ${ }^{[24]}$ 、慢性淋巴细胞白血病 $B C L 2$ 基因低甲基化 ${ }^{[25]}$ 。

部分基因启动子区域 DNA 高甲基化介导的 基因沉默也在肿瘤代谢调控中发挥了作用。

FBP1、FBP2 可催化果糖-1,6-二磷酸生成果糖-6磷酸, 是糖异生的限速酶 ${ }^{[26]}$, 可以拮抗糖酵解。 在肺癌、乳腺癌、肝癌等组织中发现了 FBP1 的启 动子区域高甲基化, 其表达也随之下调 ${ }^{[27-29]}$ 。 $\mathrm{CpG}$ 岛高甲基化还使得内质网相关降解蛋白 3 的表达 量下降, GLUT1 通过蛋白酶体的分解减少, 表达量 上升, 导致葡萄糖摄取量增加 ${ }^{[30]}$ 。PI3K/AKT/ mTOR信号通路在肿瘤葡萄糖代谢的调控中发挥 了核心作用, 该通路激活可增加 HIF-1 $\alpha$ 以及GLUT1 和糖酵解相关代谢酶的表达 ${ }^{[31-32]}$ 。有报道表明, 肿瘤组织中存在着 $\mathrm{PTEN}^{[33]} 、 \mathrm{VHL}^{[34]}$ 、脯氨酸差弪化 酶 $^{[35]}$ 等的启动子甲基化, 这些抑癌基因的沉默使 得 $\mathrm{PI} 3 \mathrm{~K} / \mathrm{AKT} / \mathrm{mTOR}$ 信号通路激活, 有氧糖酵解 增强。而在 LKB1/AMPK/mTOR 通路中, LKB1 通 过激活 AMPK 抑制 mTOR $^{[36]}$ 。研究者在 $20.16 \%$ 的肺癌组织中发现了 LKB1 启动子甲基化, 并使其 表达量降低以解除对 mTOR 的抑制 ${ }^{[37]}$ 。FBP2 可 以上调细胞内 $\mathrm{AMP} / \mathrm{ADP}$ 水平, 激活 $\mathrm{AMPK}$ 以抑 制 mTOR, 故 FBP2 的启动子甲基化也参与了有氧 糖酵解的调控 ${ }^{[38]}$ 。

\section{2 组蛋白修饰与肿瘤代谢}

组蛋白是真核细胞染色质中高度保守的结构 蛋白。构成染色质的基本结构单元核小体由核心 组蛋白 H2A、H2B、H3、H4 各两个拷贝形成的八聚 体与接头组蛋白 H1 结合 $147 \mathrm{bp}$ 的 DNA 构成。核 心组蛋白氨基端肽链上的氨基酸残基可在多种组 蛋白表观修饰酶的作用下被共价修饰，修饰的类 型包括甲基化、磷酸化、酰基化、泛素化等 ${ }^{[39]}$ 。为 精确调控“组蛋白密码”, 细胞采用了一系列酶或 结合蛋白来产生、消除或识别这些翻译后修饰, 这 些蛋白被称为书写器、擦除器和阅读器。这些书 写器和擦除器往往具有修饰位点、修饰类型的特 异性,同时可以招募相关蛋白和转录因子至基因 组的特定位置以调控相关基因的表达 ${ }^{[40-41]}$ 。

研究发现,相较于正常代谢的细胞,肿瘤细胞 中存在组蛋白修饰异常, 如部分位点的组蛋白甲 基化水平升高或乙酰化缺失等。这些异常存在的 组蛋白修饰常作为某些肿瘤的标志物 ${ }^{[7]}$ 。组蛋白 修饰在一些肿瘤细胞中通过调节相关基因表达从 而直接或间接影响细胞内的代谢过程,进而发挥 相应的调节作用。

\section{1 组蛋白甲基化与肿瘤代谢}

组蛋白甲基化是指主要发生在核心组蛋 白 $\mathrm{H} 3$ 和 $\mathrm{H} 4$ 氨基端上的赖氨酸或精氨酸残基的甲 基化修饰,包括 H3K4、H3K9、H3K36 和 H4K20 等 位点。与 DNA 甲基化类似,组蛋白甲基化由组蛋 白甲基化转移酶催化,受 SAM/SAH 比值影响。其 中,赖氨酸可在 HKMT 的催化下被单甲基化、二甲 基化或三甲基化,精氨酸可在 PRMT 的催化下被 单甲基化或二甲基化 ${ }^{[42]}$, 而这些酶同时也可以甲 基化非组蛋白底物。甲基化的位点、水平和类型 的多样性使其可编码更多的信息, 从而参与异染 色质形成、DNA 修复、基因组印迹等细胞的生物学 活动 ${ }^{[43]}$ 。一般认为, H3K4、H3K36、H3K79 的三 甲基化与基因表达激活相关,而 H3K9、H3K27 的 三甲基化则多与基因表达沉默相关 ${ }^{[44]}$ 。

HKMT 表达异常可导致多个位点的组蛋白赖 氨酸甲基化水平改变,与肿瘤的发生和发展相 关。如 $\mathrm{H} 3 \mathrm{~K} 4$ 甲基化主要由 $M L L$ 基因维持, $M L L$ 基 因如果在血液细胞中发生易位,会与其他蛋白基 因生成融合蛋白导致 H3K4 高度甲基化, 并因此改 变基因的正常表达,诱导促癌基因表达,使得血液 
细胞分化异常, 造成血液系统肿瘤的发生 ${ }^{[45]}$ 。又 如多梳抑制复合物介导的组蛋白异常的甲基化状 态可引起细胞癌变。多梳抑制复合物的核心组成 蛋白包括 EZH2/EZH1、EED、SUZ12、RBAP48 和 $\mathrm{AEBP} 2$ 。EZH2/EZH1 与 EED 、SUZ12 结合后具 有 H3K27 的甲基化活性。研究表明, 许多肿瘤细 胞中 $\mathrm{EZH} 2$ 过表达 ${ }^{[46]}$ 。此外, EZH2 的催化活性中 心氨基酸突变可引起 H3K27 甲基化水平上升和受 多梳抑制复合物调控的下游基因沉默, 导致淋巴 瘤细胞增殖 ${ }^{[47-48]}$ 。已有研究发现, PRMT 在多种 肿瘤细胞中过度表达,但其对疾病发生的影响研 究仍处于相对早期阶段 ${ }^{[49]}$ 。如乳腺癌细胞中PRMT1 过表达使肿瘤细胞更易于生存和侵人 ${ }^{[50]}$ 。PRMT1 和MLL1形成复合物并一定程度上导致了白血病 的发生 ${ }^{[51]}$ 。这些研究表明, 组蛋白甲基化水平和 甲基化酶的活性受肿瘤代谢的影响, 又反过来对 肿瘤细胞生理代谢具有不可忽视的作用, 提示其 作为相关药物靶点的价值。

与甲基转移酶相对应,去甲基化转移酶在肿 瘤发生中也具有重要作用。组蛋白赖氨酸的去甲 基化由组蛋白赖氨酸去甲基化酶介导,包含 $\alpha$ 酮 戊二酸依赖性 JmjC 结构域蛋白家族和黄素腺嘌 呤二核苷酸依赖性 $\mathrm{LSD}^{[52]}$ 。JmjC 结构域蛋白家族 去甲基化酶的调控与 TET 类似, 可以被 $\alpha$ 酮龙二 酸激活,并被2-羟基戊二酸酯、琥珀酸和延胡索酸 抑制, 能够介导三甲基化赖氨酸甲基化消除。LSD 是另一类去甲基化酶, 与单胺氧化酶同源, 由于催 化化学机制的限制, 只能催化单甲基化和二甲基 化赖氨酸的甲基消除。其中 LSD 1 是一个被广泛 研究的去甲基化酶, 它能够与许多蛋白质直接发 生相互作用, 参与复合物的调节功能。如LSD1是 MLL1复合物的一个亚基, 可对 H3K4me2和H3K9me2 进行动态可逆催化, 相关位点甲基化水平的变化 可影响血液细胞的分化和血液肿瘤的生长 ${ }^{[53]}$ 。

\section{2 组蛋白乙酰化与肿瘤代谢}

组蛋白乙酰化主要发生在组蛋白尾部的赖氨 酸残基上。组蛋白乙酰基转移酶和组蛋白去乙酰 化酶共同调控了乙酰化修饰的建立与去除, 两者 的功能异常与疾病的发生密切相关 ${ }^{[54]}$ 。一般而 言, 组蛋白的乙酰化可改变局部染色质的电荷性 质及微环境, 使得染色质结构开放, 利于转录因子 结合, 促进基因转录, 而去乙酰化则抑制转 录 ${ }^{[55]}$ 。相关研究表明, 肿瘤细胞内的组蛋白乙酰
化水平往往较高, 这与其旺盛的转录活动相适 应。组蛋白乙酰化水平主要受乙酰辅酶 $\mathrm{A}$ 含量的 调控。ACL 可以将柠檬酸转化为乙酰辅酶 $\mathrm{A}$, 在 肿瘤细胞中旺盛的糖酵解增强了底物柠檬酸的供 给, 同时 ACL 的表达和活性均上调, 这使得乙酰辅 酶A合成增加, 组蛋白乙酰化水平升高 ${ }^{[56]}$ 。C-MYC 也可以通过上调组蛋白乙酰基转移酶正调控组蛋 白乙酰化 ${ }^{[57]}$ 。

研究发现,在实体瘤和血液系统疾病患者的 细胞中, 组蛋白乙酰基转移酶的基因有遗传突变, 如 $\mathrm{p} 300 / \mathrm{CBP}$ 基因失活、突变等 ${ }^{[58]}$ 。但肿瘤的发 生是否直接来源于组蛋白乙酰基转移酶突变从而 导致细胞内异常的乙酰化水平还莫衷一是。动物 实验结果表明,突变的乙酰基转移酶基因会导致 白血病发生,但这一观点仍需要更多的证据支 持。最近的研究结果揭示, 组蛋白乙酰基转移酶 还能够乙酰化 C-MYC、P53、PTEN 等非组蛋白等, 说明组蛋白乙酰基转移酶发挥活性的分子机制对 肿瘤有直接的影响 ${ }^{[59]}$ 。

人体中共有两大类组蛋白去乙酰化酶, 其中 锌离子依赖的 HDAC 表达在不同的肿瘤细胞中被 检测到的差异很大。如在前列腺癌和胃癌中 HDAC1 高表达, 在结肠癌、宫颈癌和胃癌中HDAC2 高表达 ${ }^{[60]}$ 。尽管不同亚型的 HDAC 在不同肿瘤 中发挥的功能不尽相同, 但这些蛋白的异常表达 都可能在某种程度上促进肿瘤细胞的增殖和生 存。在某种意义上, HDAC也可作为相关药物的 靶点。Sirtuins 成员构成另一类组蛋白或非组蛋 白 (尤其是线粒体蛋白)去乙酰化酶家族, 其酶活 性的发挥依赖于代谢产物 $\mathrm{NAD}^{+}$,参与抗衰老途径 并与许多疾病尤其是肿瘤的发生有关。如SIRT6 可以直接与 HIF-1 $\alpha$ 和 C-MYC 相互作用, 并通过 组蛋白去乙酰化作用抑制其转录, 在结肠癌、胰腺 癌和肝癌中均检测到了 SIRT6 缺失 ${ }^{[61]}$; SIRT7 对 H3K18Ac 去甲基化作用具有选择性催化活性, 也 可以直接抑制 C-MYC ${ }^{[62]}$; 与 SIRT6/7相反, SIRT2 通过间接稳定 C-MYC 参与肿瘤代谢调控, 其对 H4K16Ac 去甲基化作用有催化活性, 导致泛素蛋 白连接酶NEDD4 表达受到抑制, NEDD4可以通 过泛素化途径负调控 C-MYC, 而SIRT2 本身在肿 瘤细胞系中被 MYC 上调, 构成一个正反馈循环, 通过 MYC 依赖性转录正调控糖酵解和谷氨酰胺 代谢, 促进肿瘤发生 ${ }^{[63]}$ 。 


\section{3 组蛋白非乙酰酰基化与肿瘤代谢}

近年来随着研究的深人和质谱技术的发展, 组蛋白非乙酰的酰基化修饰被鉴定出来,包括但 不限于组蛋白的甲酰化、丙酰化、丁酰化、巴豆酰 化、2-差基异丁酰化、琥珀酰化、苯甲酰化、 $\beta$-差基 丁酰化、豆冦酰化等 ${ }^{[64-67]}$ 。这些新型修饰的发现 丰富了组蛋白修饰的内容, 说明组蛋白翻译后修 饰的调控层次更加丰富多样, 有望为更深人地探 究组蛋白修饰的生物学意义提供新的研究资料。 但新型组蛋白酰基化在前期研究鉴定过程中因一 些酰基化类型的结构较为相似, 在质谱上可能区 分度不高。其解决方法一是质谱样品准备时采用 特异性抗体进行富集, 二是对质谱数据核心算法 进行优化处理。经过多轮探索和深人研究, 多种 新型酰基化修饰才被鉴定出来。

组蛋白翻译后修饰的本质都是对氨基酸进行 化学改变,而酰基化修饰一般发生在组蛋白尾部 的赖氨酸上, 其建立和去除是一个动态调节的过 程, 依赖于细胞内的代谢环境和执行催化反应的 酶等相应蛋白表达。针对非乙酰化酰基化特异性 的酰基催化酶并没有鉴定出来, 但之前鉴定的乙 酰基转移酶具有催化其他酰基酰化的能力, 包 括 GNAT、MYST(Moz-Ybfz/Sas3-Sas2-Tipbo) 乙酰 基转移酶家族、p300/CBP 家族等 ${ }^{[68-69]}$ 。其中, p300 是目前关注最多的酰基转移酶, 它除了可以 催化乙酰化外, 还可以催化组蛋白的丙酰化、丁酰 化、巴豆酰化、羟基丁酰化、琥珀酰化和成二酰 化 ${ }^{[70-72]}$;GNAT 和 MYST 家族成员却对非乙酰类的 酰基催化具有更严苛的条件,如乙酰化酶氨合成 通用控制蛋白 $5 、 \mathrm{p} 300 / \mathrm{CBP}$ 相关因子、赖氨酸乙酰 基转移酶 5 可以在体外催化丙酰化的完成, 通用 控制蛋白 5 和 $\mathrm{p} 300 / \mathrm{CBP}$ 相关因子可以在体外催 化丁酰化,但酶的催化效率较乙酰化降低 ${ }^{[73-75]}$ 。

各种组蛋白酰基化的供体为酰基辅酶 $\mathrm{A}$,酰 基转移酶似乎对于各种酰基化辅酶 $\mathrm{A}$ 并没有选择 性, 因此推测组蛋白酰基化的类型和丰富程度取 决于周围环境中酰基辅酶 $\mathrm{A}$ 的相对浓度,各种不 同比例酰基辅酶 $\mathrm{A}$ 则存在相应的竞争关系。如上 所述, 在多细胞生物中, 乙酰辅酶 $\mathrm{A}$ 主要是三羧酸 循环中伴随 ATP 生成过程产生的, 同时乙酰辅 酶 $\mathrm{A}$ 是组蛋白酰基的主要供体。当 $A C L$ 基因被敲 除后, 组蛋白乙酰化水平降低, 巴豆酰化水平增 高 ${ }^{[72]}$, 与此同时,组蛋白巴豆酰化水平提高可作
为一个信号, 提示细胞在代谢过程中增加乙酰辅 酶 $\mathrm{A}$ 的产出, 以维持细胞正常的生理代谢过程。 这不仅说明酰基辅酶 $\mathrm{A}$ 之间可能存在潜在的竞争 关系, 也说明细胞能根据周边动态变化的营养环 境, 动态运用组成相似或相近的化学分子来影响 相关基因表达调控,从而维持细胞生存的稳态。

细胞中非乙酰化酰基辅酶 $\mathrm{A}$ 的浓度很大程度 上取决于细胞中脂肪酸代谢的活跃程度。如在细 胞培养基中加人标记的短链脂肪酸, 后续可以在 组蛋白修饰上发现标记的放射性，说明短链的脂 肪酸可以转变成为非乙酰酰基辅酶 $\mathrm{A}$,从而对组 蛋白进行酰基化修饰 ${ }^{[67,76]}$ 。ACSS2 是产生巴豆酰 辅酶 $\mathrm{A}$ 重要的酶,敲除ACSS2会导致组蛋白巴豆酰 化水平下降 ${ }^{[77]}$ 。有趣的是, 在众多肿瘤中, ACSS2 表达量大幅度上升, 与肿瘤的发生程度呈正相 关 ${ }^{[78-79]}$ 。但 ACSS2 表达量的变化对于非乙酰酰化 组蛋白的影响还没有彻底揭示出来。且 ACSS2 的 活性可被乙酰化抑制、被 SIRT1 介导的去乙酰化 过程激活 ${ }^{[80]}$, 说明细胞对于 ACSS2 的调控是复 杂、多层次的。

与乙酰化类似,非乙酰酰基化修饰的去除主 要由 HDAC 和 Sirtuins 两类擦除体完成。Sirtuins 家族有 7 个成员, 具有广泛的去酰基化修饰的能 力, 然而各个成员对于不同碳链长度的非乙酰化 酰基化修饰去除能力则不尽相同。如 SIRT3 可以 去除巴豆酰化和 $\beta$-羟基丁酰化修饰,SIRT5 可以 催化去除琥珀酰化、戊二酰化和丙二酰化,但其酶 活性都很低 ${ }^{[81-84]}$ 。相较于 Sirtuins 家族, 对于HDAC 家族去除蛋白酰基化尤其是非乙酰酰基化的能 力及特异性知之甚少, 其作用的底物范围、位点 特异性和酶动力学参数等均有待深人研究。

近来研究表明,组蛋白巴豆酰化修饰不仅是 细胞对于周围营养变化的一种应急反应机制, 同 时也是一种良好的肿瘤标志物。如巴豆酰化的表 达水平在肝癌、胃癌和肾癌中下调, 而在甲状腺 癌、食管癌、结肠癌、胰腺癌和肺癌中上调, 这表 明巴豆酰化在不同肿瘤中可能表现出不同的特 性 ${ }^{[85-89]}$ 。而巴豆酰化水平的变化则很可能与各种 肿瘤细胞的代谢途径和代谢水平变化有关, 关于 这一过程的具体调控机制研究仍不充分。

\section{3 mRNA的m6A 修饰与肿瘤代谢}

与 DNA 修饰和组蛋白修饰类似, 近年来RNA 
的各种修饰及其功能引起了研究者们的广泛关 注, 以 mRNA 修饰为代表的表观转录组研究成为 了广义表观遗传学领域又一个新兴热点。在各类 RNA 修饰中, 甲基化是最主要的修饰形式, $m 6 A$ 和 5-甲基胞嘧啶是其中具有代表性的两种修饰类 型, 尤其以丰度最高的 $\mathrm{m} 6 \mathrm{~A}$ 研究最为深人。 $\mathrm{m} 6 \mathrm{~A}$ 修饰发现较早, 但其催化酶和识别结合蛋白的发 现和鉴定则是近些年的进展。其中, METTL3、 METTL4和 WATP 复合体可以催化 m6A 形成 ${ }^{[90-91]}$, 而 FTO 和 ALKBH5 可以去除甲基化 ${ }^{[92-93]}, \mathrm{m6A}$ 修 饰的结合识别蛋白一般包含 YTH 结构域。 $\mathrm{m} 6 \mathrm{~A}$ 和 $\mathrm{m} 6 \mathrm{~A}$ 结合蛋白的发现证明了这种修饰类型是可逆 的, 细胞根据其所处的发育时期、生理状态的不同 完成动态的调控过程。

FTO 催化 m6A 去甲基化的过程要经历复杂 的中间反应步骤, 而 ALKBH5 可直接催化 $\mathrm{m} 6 \mathrm{~A}$ 为 腺嘌呤。研究表明, ALKBH5 倾向于结合特异的 $\mathrm{m} 6 \mathrm{~A}$ 修饰的单链 RNA, 从而催化 $\mathrm{m} 6 \mathrm{~A}$ 去甲基化。 此外, 识别结合这种修饰的蛋白主要是含有 YTH 结构域的蛋白家族，包括 YTHDF 1、YTHDF2、 YTHDF3、YTHDC1 和 YTHDC2 等 ${ }^{[94-97]}$ 。代谢中间 产物对 RNA m6A 修饰的调控与 DNA 甲基化和去 甲基化修饰基本相同, 如 SAM/SAH 比值影响 $\mathrm{m} 6 \mathrm{~A}$ 修饰, 2 -差基戊二酸酯、琥珀酸和延胡索酸抑 制 FTO 的 m6A 去甲基化作用。

最近研究发现, FTO 在急性髓细胞白血病中 高表达, 针蛋白重复序列、细胞信号抑制因子盒蛋 白 2 和视黄酸受体 $\alpha$ 基因抑制白血病细胞生长或 介导药物应答的基因在急性髓细胞白血病样本中 受到抑制, 并且这些基因表达的 mRNA 受到FTO m6A 去甲基化酶的调节 ${ }^{[98]}$ 。而 ALKBH5 能够维持 恶性胶质瘤细胞的干性, 在恶性胶质瘤细胞中, ALKBH5 通过 lncRNA FOXM1-AS 介导识别并催 化转录因子 FOXM1 上 $\mathrm{m} 6 \mathrm{~A}$ 修饰的去甲基化, 从而 使其处于较高的表达水平 ${ }^{[99]}$ 。此外, YTHDC2 在 多种肿瘤细胞系中的表达显著高于正常的干细 胞 ${ }^{[100]}$, 这表明 $\mathrm{m} 6 \mathrm{~A}$ 的水平变化是细胞生理状态 的一个重要指标, 失调的 $\mathrm{m} 6 \mathrm{~A}$ 信号会影响细胞的 生理代谢进程, 导致正常的生理过程发生紊乱。 之前的研究表明, 异柠檬酸脱氢酶在神经胶质瘤 和白血病中有较高的突变率从而使得 $\alpha$ 酮戊二酸 转变为致癌的代谢物 2-差基戊二酸酯, 导致 DNA 和组蛋白的高度甲基化, 从而诱发肿瘤 ${ }^{[86]}$ 。最新
的研究显示, 虽然 2-羟基戊二酸酯的累积会导致 肿瘤，但同时也上调了 $M Y C 、 C E P B P A$ 等基因 的 mRNA 的 m6A 修饰, 后者被 YTHDF2识别后降 解, 抑制肿瘤的葡萄糖和氨基酸代谢 ${ }^{[101]}$ 。

$\mathrm{mRNA}$ 的 $\mathrm{m} 6 \mathrm{~A}$ 修饰可以在转录后水平微调 基因表达，促进翻译并缓冲 miRNA 的抑制作用， 进而通过信号通路参与肿瘤细胞代谢调控。在一 些类型的白血病中, METTL3 可以增强 BCL2 和 PTEN 的 m6A 修饰和表达水平, 影响糖代谢并产生 致癌作用 ${ }^{[102]}$ 。在子宫内膜癌中 METTL3 下调和 METTL4 突变导致了 AKT 的激活,进而增强有氧 糖酵解和细胞增殖速度 ${ }^{[103]}$ 。非编码 RNA 的 m6A 修饰也可以影响其对基因表达的调控。METTL3 可以增强原始 miRNA 的 m6A 修饰, 并加速其成 熟 ${ }^{[104]}$ 。m6A 修饰的 circRNA 具有蛋白编码能力, 单个 m6A 修饰位点就可以推进翻译的开始 ${ }^{[105]}$ 。 大量 IncRNA 具有 $\mathrm{m} 6 \mathrm{~A}$ 修饰, 这些修饰可以影响 lncRNA 和 RNA 结合蛋白、特定 DNA 位点的相互 作用。IncRNA MALAT1具有一系列的 m6A 修饰 位点,这些修饰可以改变它的结构、细胞定位以及 与一些蛋白的亲和力, 影响有氧糖酵解的调控 ${ }^{[106]}$ 。

\section{4 非编码 RNA 与肿瘤代谢}

非编码 RNA 是指不编码蛋白质序列, 不能通 过翻译生成蛋白质的 RNA, 它们在生命活动中也 有着重要的功能。其中直接参与细胞生命活动的 称为“管家”非编码 RNA, 主要包括核糖体 RNA、转 运 RNA 等; 而参与基因表达调控的称为调控性非 编码 RNA, 主要包括 miRNA、lncRNA、circRNA 等 ${ }^{[107]}$ 。相对于癌旁组织, 肿瘤中存在着差异表达 的非编码 RNA，它们参与调节肿瘤细胞的代谢。 与其他表观遗传机制相似, 非编码 RNA 可以调控 关键癌基因、抑癌基因的表达,进而通过肿瘤中的 信号通路调控细胞代谢, 非编码 RNA 也可以直接 调控代谢酶和转运蛋白的表达。

\section{1 miRNA 与肿瘤代谢}

miRNA 是一类单链非编码小 RNA, 由内源基 因编码, 长度约为 $22 \mathrm{bp}$, 可以靶向 mRNA 并进行 碱基配对, 导致转录后抑制 ${ }^{[108]}$ 。

在葡萄糖代谢中, miRNA 参与调控葡萄糖转 运蛋白以及糖酵解关键酶的表达。GLUT1、GLUT3 和 GLUT4 在多种肿瘤中过表达 ${ }^{[109]}$ 。乳腺癌研究 证明, miR-22 可以直接靶向 GLUT1 ${ }^{[110]}$; 而肾细胞 
癌样本 miR-1291 相比周围正常组织表达降低, 进 而导致GLUT1过表达 ${ }^{[111]}$; GLUT3 对葡萄糖的亲和 力和转运能力都较高, 在膀胱癌 $\mathrm{T} 24$ 细胞系中, miR-195-5p 可以通过调节 GLUT3表达来抑制葡萄 糖摄取和细胞增殖 ${ }^{[112]}$ 。在糖酵解反应中, miR-143、 miR-497可以直接靶向已糖激酶 ${ }^{[113-114]}$, miR-122 可以直接靶向果糖 1,6 二磷酸醛缩酶 ${ }^{[115]}, \mathrm{miR}-1256$ 可以直接靶向磷酸甘油酸激酶 $1^{[116]}, \mathrm{miR}-122$ 、 miR-326 可以抑制 PKM2 的表达 ${ }^{[117-118]}$, miR-124 靶向 PKM 的剪接体多聚嘧啶串结合蛋白 1 以诱导 PKM 亚型表达从 PKM2 转换为PKM1 ${ }^{[119]}$ 。这些能 够负调控糖酵解酶表达的miRNA 作为抑癌因子在 多种人类肿瘤组织中表达降低 ${ }^{[85]}$ 。糖酵解途径 生成的丙酮酸需要通过乳酸脱氢酶转化为乳酸并 生成 $\mathrm{NAD}^{+}$, 以满足旺盛的能量和物质代谢需求。 有研究表明, miR-34a、miR-34c、miR-369-3p 和 $m i R-374 a$ 具有靶向乳酸脱氢酶的潜力 ${ }^{[120]}$ 。此外, miR-186和miR-145可以抑制HIF-1 $\alpha^{[121-122]}$, miR-145 和miR-34a 可以在多种肿瘤中抑制 C-MYC ${ }^{[123-124]}$, 通过肿瘤信号通路参与调节葡萄糖代谢。

在脂质代谢中, miRNA 参与了脂肪酸氧化、 三酰甘油和胆固醇代谢的调控。肝脏是人体脂肪 代谢的重要场所,食物中的三酰甘油和胆固醇酯 通过乳糜微粒运输至肝细胞后, 可在肝细胞中被 水解。miR-122 可在肝脏中调节脂肪和胆固醇代 谢 $^{[125]}$, 并在肝细胞癌中表达下调 ${ }^{[126]}$ 。在体外和 细胞实验中, miR-122 可使肝细胞脂肪氧化增加, 胆固醇和脂肪酸合成速率降低, $\mathrm{AMP} / \mathrm{ADP}$ 水平上 升, AMPK 激活 ${ }^{[127]}$ 。在小鼠中敲除 $m i R-122 a$ 会出 现脂肪性肝炎、肝硬化、肝细胞癌等病变 ${ }^{[125]}$ 。 ACSL1 催化细胞中脂肪酸代谢的第一步反应, 使 其活化并参与三酰甘油的合成。miR-205 可以直 接靶向 ACSL1, 下调其表达以抑制三酰甘油合 成 ${ }^{[128]}$ 。肝癌中miR-205 表达下调, 使得肿瘤细胞 脂质代谢异常 ${ }^{[129]}$ 。

在肿瘤氨基酸代谢调控中, miR-23 家族和 CMYC 发挥了核心作用。在谷氨酰胺分解代谢中, 谷 氨酰胺可在谷氨酰胺酶催化下脱氨基生成谷氨 酸。类似地, 在脯氨酸分解代谢中, 脯氨酸也可以 在脯氨酸氧化酶/脱氢酶的作用下转化为谷氨 酸 ${ }^{[130]}$ 。谷氨酸可进一步脱氨基生成 $\alpha$ 酮戊二 酸 进人三羧酸循环, 为细胞供能。在多种肿瘤中, CMYC可通过下调 miR-23a 和 miR-23b 来增强两种
miRNA 直接靶向的谷氨酰胺酶表达, 促进谷氨酰 胺分解生成谷氨酸, 进而为细胞供能 ${ }^{[131]}$; 同时 CMYC 可通过上调 miR-23b*抑制脯氨酸氧化酶/脱 氢酶表达,进而抑制脯氨酸的分解代谢 ${ }^{[132]}$ 。

\section{2 circRNA 与肿瘤代谢}

circRNA 是由 mRNA 内含子或外显子环化形 成的共价闭合单链 RNA, 在真核细胞中广泛存

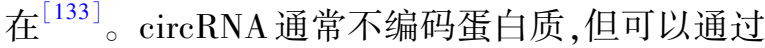
多种机制调控基因表达。它可以与 mRNA 竞争性 结合 miRNA, 减弱 miRNA 对靶基因表达的抑制, 这一过程被称为 miRNA 海绵作用, 是 circRNA 发 挥生物学功能最主要的机制 ${ }^{[134]}$ 。circRNA 还可与 lncRNA或RNA结合蛋白相互作用,参与转录的调节。

在糖酵解中, circRNA 可以直接调节转运蛋 白和代谢酶, 或与信号通路和转录因子相互作用 来参与调控有氧糖酵解。胰腺中 circHIPK3 含量 很高, 可以降低 GLUT2 的表达 ${ }^{[135]}$, 还可以通过对 miR-124 的海绵作用诱导瓦博格效应 ${ }^{[136]}$ 。在乳腺 癌中 HIF-1 $\alpha$ 可以上调 circDENND4C 并促进细胞 增殖, 但与有氧糖䣲解间因果关系尚不明确 ${ }^{[137]}$ 。 在细胞实验中,缺氧条件下 circ_0010729可以通过 对过表达的 miR-186 的海绵作用解除其对靶 向 HIF-1 $\alpha$ 表达的抑制, 增强糖酵解 ${ }^{[138]}$ 。在多种 肿瘤中, circRNA_001569 和 circBIRC6 可以对miR145 产生海绵作用,circBIRC6 还可以对 miR-34a 产生海绵作用,解除两种 miRNA 对 C-MYC 的抑 制, 增强糖酵解 ${ }^{[139-140]}$ 。

然而, 虽然有很多证据提示 circRNA 参与了 氧化磷酸化、脂肪代谢和氨基酸代谢的调控,这一 调控在人类肿瘤体系中的实验证据并不充分。

\section{$4.3 \operatorname{lncRNA}$ 与肿瘤代谢}

$\operatorname{lncRNA}$ 是一类由 RNA 聚合酶转录生成的、 不可翻译生成蛋白质的、长度在 200 个核苷酸以 上的转录物。 IncRNA 可以根据表达来源分为六 种类型: 基因间 lncRNA(位于两个可编码转录本 之间)、双向 IncRNA(蛋白质编码基因的启动子反 向转录的产物)、有义/反义 RNA(与蛋白质编码基 因外显子或其反义链同源的片段)、内含 子 lncRNA (与蛋白质编码基因的内含子同源)、增 强子 RNA(增强子的转录本)。lncRNA 可以通过 多种可能的机制参与基因表达调控:指南作用(与 转录调节因子结合,引导其靶向目标序列)、支架 作用(在核糖核蛋白复合物的形成过程中充当支 
架)、诱饵作用 (与转录调节因子结合, 阻止其与靶 基因的相互作用)、miRNA 海绵、增强子 RNA 充当 反式激活 $\mathrm{RNA}^{[141]}$ 。

lncRNA 在葡萄糖代谢中参与调控转运体蛋 白和代谢酶的表达, 并通过 LKB1/AMPK、HIF 等 信号通路调节有氧糖酵解。多种 lncRNA 在肿瘤 中调控 GLUT 家族的表达和亚细胞定位。在鼻咽 癌中反义 RNA ANRIL 表达升高, 并正向调控GLUT1 的表达, 增加葡萄糖摄取 ${ }^{[142]}$ 。在肝细胞癌中HOX 转录反义 RNA 可以诱导 GLUT1 并激活mTOR信号 通路, 增强糖酵解 ${ }^{[143]}$ 。lncRNA MACC1-AS1 在胃 癌中高表达, 可通过增加 GLUT1在细胞膜上的分 布来增加葡萄糖摄取 ${ }^{[144]}$ 。lncRNA 还可以正向调 控已糖激酶 2、PKM2、丙酮酸羧化酶等代谢酶, 从 而增强糖酵解。IncRNA PVT1在多种肿瘤中过表 达, 其可通过调节 miR-497/已糖激酶 2 轴来增强 葡萄糖代谢, 进而产生致癌作用 ${ }^{[114]}$ 。在肝细胞癌 中, lncRNA H19 可由 miR-675 通过激活早期生长 反应蛋白 1 途径诱导而表达, 进而提高下游 PKM2 的表达 ${ }^{[145]}$ 。丙酮酸羒化酶参与调节多种 代谢过程,包括葡萄糖代谢、糖异生和从头脂肪酸 合成。IncRNA GCASPC 可以与丙酮酸羧化酶相互 作用, 降低丙酮酸羧化酶的蛋白质稳定性。在胆 囊癌中, GCASPC 下调, 并与肿瘤进展相关 ${ }^{[146]}$ 。

LKB1 是 AMPK 的上游调节剂, 可以磷酸化 并激活 AMPK, 进而抑制 mTOR 的活性, 调节细胞 增殖和能量代谢。敲低 $L K B I$ 可促进肿瘤生长、葡 萄糖摄取、ATP生产和大分子合成 ${ }^{[147]}$ 。LINC00473 在人非小细胞肺癌中上调, 其表达量与 LKB1 的活 性呈负相关 ${ }^{[148]}$ 。lncRNA NBR2 可在代谢应激下 由 LKB1/AMPK 信号传导途径诱导表达。而NBR2 可增强 AMPK 的活性, 形成正反馈调节, 降低糖酵 解, 发挥抑癌作用 ${ }^{[149]}$ 。

多种 IncRNA 参与了 HIF-1 $\alpha$ 对有氧糖䣲解 的调控。在缺氧条件下, lincRNA-p 21 被 HIF-1 $\alpha$ 上调, 并反过来增强 HIF- $1 \alpha$ 的蛋白质稳定性, 建 立了正反馈调节 ${ }^{[150]}$ 。在正常肝细胞系 L02 中, 亚 砷酸盐处理可上调葡萄糖转运蛋白、糖酵解相关 代谢酶和 lncRNA MALAT1 的表达, 其中 MALAT1 可以诱导 HIF- $1 \alpha$ 与 VHL 解离, 从而阻止 VHL介

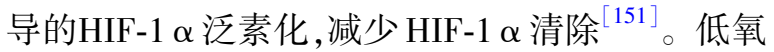
条件可以诱导 lncRNA H19 表达, 其参与了低氧诱 导的癌细胞信号转导过程, 从而调节葡萄糖的代
谢 ${ }^{[152]}$ 。LINK-A 是一种在三阴性乳腺癌细胞的细 胞质中表达的 IncRNA, 可诱导乳腺肿瘤激酶募集 到表皮生长因子-糖蛋白 $\mathrm{nmb}$ 复合物中,并增强其 活性。乳腺肿瘤激酶可在酪氨酸 565 处磷酸化 HIF-1 $\alpha$,然后通过干扰脯氨酸564的羟基化来稳定 HIF-1 $\alpha^{[153]}$ 。linc-ROR 在低氧条件下表达,并通过对 miR-145的分子海绵作用调节 HIF-1 $\alpha$ 表达 ${ }^{[122]}$ 。

细胞中 p53 缺失或突变可导致线粒体呼吸损 伤并增加糖酵解。p 53 可调控葡萄糖转运蛋白 (如 GLUT1 和 GLUT4) 以及一些糖酵解基因,包括磷酸 甘油酸突变酶、6-磷酸果糖激酶 1 等的表达 ${ }^{[154]}$ 。 几种 $\operatorname{lncRNA}$ 直接或间接受 $\mathrm{p} 53$ 调控。突变体 $\mathrm{p} 53$ (N340Q/L344R) 可以通过 lncRNA CUDR上调 PKM2 表达并促进肝癌的发展 ${ }^{[155]}$ 。lncRNA母体 表达基因 3 的过表达可诱导 $\mathrm{p} 53$ 表达和 $\mathrm{p} 53$ 下游 靶基因的激活 ${ }^{[156]}$ 。p53 的反义转录物 (wrap53)通

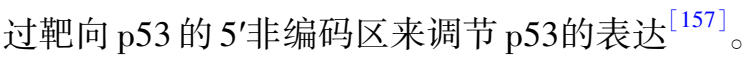
敲除成纤维细胞中的 MALAT1 刺激DNA 损伤修复, 可以导致 $\mathrm{p} 53$ 及其下游靶基因激活 ${ }^{[158]}$ 。DNA受 损后, linc-ROR 可以作为 $\mathrm{p} 53$ 的阻遏物 ${ }^{[159]}$ 。

\section{5 结 语}

表观遗传修饰的动态变化和代谢组之间的交 叉会话是细胞适应外界营养条件变化和自身生命 维持的一个重要方面。细胞中表观遗传修饰的建 立依赖于代谢过程中产生的重要的中间产物, 其 修饰类型的变化作为响应细胞代谢变化的调控结 果。另外, 表观遗传修饰或者代谢通路中蛋白质 的突变会导致某些重要基因表达的失调, 反过来 有助于肿瘤的发生。

在肿瘤细胞中, 表观遗传修饰和细胞的代谢 是高度交织的。一方面, 癌化细胞中基因表达网 络驱动的生理代谢过程通过影响 DNA 和组蛋白 修饰酶等表观调控蛋白重塑表观遗传景观,使得 肿瘤细胞具有独特的表观遗传信息谱。另一方 面,表观遗传机制的改变导致了与细胞生理代谢 相关基因表达的变化,从而影响整个代谢组的进 程。这说明表观遗传修饰和代谢组之间相互交织 的关系在肿瘤的发生和发展中扮演非常重要的角 色,特别是在肿瘤细胞所显现出的无限增殖、多能 性等方面。深刻理解表观遗传修饰与代谢组学之 间的关系, 有助于新分子靶标的发现, 对开发针对 性的药物具有极大的现实意义。 
目前很多研究结果是基于细胞培养系统,在 某种程度上很难代表细胞在体内的生长环境, 而 细胞的生长环境对于细胞代谢具有重要意义。未 来的研究要更集中于肿瘤细胞微环境对于细胞代 谢、表观遗传修饰的作用等方面, 以更接近细胞在 正常生理条件下的状态, 这对于发现新的或更有 效的分子靶标具有重要意义。

对于与表观遗传因素紧密相关肿瘤的治疗， 一方面对于还不清楚致病机制的, 需要进一步研 究导致肿瘤发生的关键性因子, 明确其所扮演的 角色, 有针对性地设计特异性药物, 对相关靶点进 行有目的性的治疗; 另一方面, 针对已经明确致病 的表观遗传因子, 可以在已有药物的基础上发展 并完善相关治疗策略, 特别是综合运用生物化学、 免疫学等手段,更有针对性地治疗肿瘤。

\section{参考文献}

[1] WARBURG O, WIND F, NEGELEIN E. The metabolismof tumors in the body $[\mathrm{J}]$. J General Physiol, 1927,8(6):519-530. DOI:10. 1085/jgp. 8. 6. 519.

[2] DEBERARDINIS R J, MANCUSO A, DAIKHIN E, et al. Beyond aerobic glycolysis:transformed cells can engage in glutamine metabolism that exceeds the requirement for protein and nucleotide synthesis $[\mathrm{J}]$. Proc Natl Acad Sci USA, 2007,104(49) : 1934519350. DOI: 10. 1073/pnas. 0709747104.

[3] HSU P P, SABATINI D M. Cancer cell metabolism: warburg and beyond $[J]$. Cell, 2008,134(5): 703707. DOI: $10.1016 /$ j. cell. 2008. 08. 021.

[4] JAENISCH R, BIRD A. Epigenetic regulation of gene expression:how the genome integrates intrinsic and environmental signals $[J]$. Nat Genet, 2003,33 (S3 ) :245-254. DOI:10. 1038/ng1089.

[5] HERCEG Z, VAISSIÈRE T. Epigenetic mechanisms and cancer:an interface between the environment and the genome $[\mathrm{J}]$. Epigenetics, 2011,6(7):804-819. DOI : $10.4161 /$ epi. 6. 7. 16262.

[6] EDEN A, GAUDET F, WAGHMARE A, et al. Chromosomal instability and tumors promoted by DNA hypomethylation $[J]$. Science, 2003,300(5618):455. DOI : 10.1126 /science. 1083557.

[7] FRAGA M F, BALLESTAR E, VILLAR-GAREA A, et al. Loss of acetylation at Lys16 and trimethylation at Lys20 of histone $\mathrm{H} 4$ is a common hallmark of human cancer $[J]$. Nat Genet, 2005,37(4):391-400. DOI: 10. $1038 / \mathrm{ng} 1531$.

[8] MENTCH S J, MEHRMOHAMADI M, HUANG L, et al. Histone methylation dynamics and gene regulation occur through the sensing of one-carbon metabolism
[J]. Cell Metab, 2015,22(5):861-873. DOI: 10 . 1016/j. cmet. 2015. 08. 024.

[9] LEE J V, CARRER A, SHAH S, et al. Akt-dependent metabolic reprogramming regulates tumor cell histone acetylation [J]. Cell Metab, 2014,20(2):306-319. DOI: $10.1016 /$ j. cmet. 2014. 06. 004.

[10] LI X, KAZGAN N. Mammalian sirtuins and energy metabolism [J]. Int J Biol Sci, 2011,7(5 ) :575-587. DOI : 10. 7150/ijbs. 7. 575.

[11] BIRD A P. CPG-rich islands and the function of dna methylation $[J]$. Nature, 1986,321(6067):209-213. DOI : $10.1038 / 321209 \mathrm{a} 0$.

[12] YEIVIN A,RAZIN A. Gene methylation patterns and expression [J]. Exs, 1993,64:523-568. DOI: 10. 1007/978-3-0348-9118-9_24.

[13] ROBERTSON K D, UZVOLGYI E, LIANG G, et al. The human DNA methyltransferases (DNMTs) 1,3a and $3 \mathrm{~b}$ : coordinate mRNA expression in normal tissues and overexpression in tumors $[\mathrm{J}]$. Nucleic Acids Res, 1999,27 (11):2291-2298. DOI: 10. 1093/nar/27. 11. 2291

[14] HAASE C, BERGMANN R, FUECHTNER F, et al. L-type amino acid transporters LAT1 and LAT4 in cancer : uptake of 3-O-Methyl-6-18F-Fluoro-L-Dopa in human adenocarcinoma and squamous cell carcinoma in vitro and in vivo $[\mathrm{J}]$. J Nucl Med, 2007,48 (12):2063-2071. DOI: 10. 2967/jnumed. 107. 04 3620 .

[15] MARTÍNEZ-CHANTAR M L, VÁZQUEZ-CHANTADA M, ARIZ U, et al. Loss of the glycine Nmethyltransferase gene leads to steatosis and hepatocellular carcinoma in mice[J]. Hepatology, 2007,47 (4) :1191-1199. DOI: 10. 1002/hep. 22159.

[16] GUO J U, SU Y, ZHONG C, et al. Hydroxylation of 5methylcytosine by TET1 promotes active DNA demethylation in the adult brain[J]. Cell, 2011,145 (3) :423-434. DOI: 10. 1016/j. cell. 2011. 03. 022.

[17] KOHLI R M, ZHANG Y. TET enzymes, TDG and the dynamics of DNA demethylation $[\mathrm{J}]$. Nature, 2013, 502(7472):472-479. DOI: $10.1038 /$ nature12750.

[18] GAMBICHLER T, SAND M, SKRYGAN M. Loss of 5hydroxymethylcytosine and ten-eleven translocation 2 protein expression in malignant melanoma $[\mathrm{J}]$. Melanoma Res, 2013,23(3):218-220. DOI:10. 1097/CMR. 0b013e32835f9bd4.

[19] KUDO Y, TATEISHI K, YAMAMOTO K, et al. Loss of 5-hydroxymethylcytosine is accompanied with malignant cellular transformation $[\mathrm{J}]$. Cancer Sci, 2012,103(4):670-676. DOI:10. 1111/j. 1349-7006. 2012. 02213. $\mathrm{x}$

[20] XIAO M, YANG H, XU W, et al. Inhibition of alphaKG-dependent histone and DNA demethylases by fumarate and succinate that are accumulated in mutations of $\mathrm{FH}$ and 
SDH tumor suppressors[J]. Genes Dev, 2012,26(12): 1326-1338. DOI:10. 1101/gad. 191056. 112.

[21] IKEGAMI K, OHGANE J, TANAKA S, et al. Interplay between DNA methylation, histone modification and chromatin remodeling in stem cells and during development [J]. Int J Dev Biol, 2009,53(2-3): 203-214. DOI: 10. 1387/ijdb. 082741ki.

[22] DESAI S, DING M, WANG B, et al. Tissue-specific isoform switch and DNA hypomethylation of the pyruvate kinase PKM gene in human cancers $[\mathrm{J}]$. Oncotarget, 2014,5(18) : 8202-8210. DOI : 10. 18632/ oncotarget. 1159.

[23] NING X, QI H, LI R, et al. Synthesis and antitumor activity of novel 2,3-didithiocarbamate substituted naphthoquinones as inhibitors of pyruvate kinase M2 isoform[J]. J Enzyme Inhib Med Chem, 2018,33 (1) : 126-129. DOI:10. 1080/14756366. 2017. 1404591.

[24] KANEKO Y,SHIBUYA M,NAKAYAMA T,et al. Hypomethylation of C-MYC and epidermal growthfactor receptor genes in human hepatocellular-carcinoma and fetal liver[J]. Jap J Cancer Res, 1985, 76 (12) : 1136-1140.

[25] HANADA M,DELIA D, AIELLO A, et al. BCL-2 gene hypomethylation and high-level expression in Bcell chronic lymphocytic-leukemia $[\mathrm{J}]$. Blood,1993, $82(6)$ : $1820-1828$.

[26] POGELL B M, MCGILVERY R W. Partial purification of fructose-1, 6-diphosphatase $[\mathrm{J}]$. J Biol Chem, 1954,208(1):149-157.

[27] DONG C, YUAN T, WU Y, et al. Loss of FBP1 by snail-mediated repression provides metabolic advantages in basal-like breast cancer $[\mathrm{J}]$. Cancer Cell, 2013,23(3):316-331. DOI:10. 1016/j. ccr. 2013. 01.022 .

[28 ] ZHANG J, WANG J, XING H, et al. Down-regulation of FBP1 by ZEB1-mediated repression confers to growth and invasion in lung cancer cells $[\mathrm{J}]$. Mol Cell Biochem, 2016,411(1-2):331-340. DOI:10. 1007/ s11010-015-2595-8.

[29] BÁRCENA-VARELA M, CARUSO S, LLERENA S, et al. Dual targeting of histone methyltransferase G9a and DNA-methyltransferase 1 for the treatment of experimental hepatocellular carcinoma $[\mathrm{J}]$. Hepatology, 2019,69(2):587-603. DOI:10. 1002/hep. 30168.

[30] LOPEZ-SERRA P, MARCILLA M, VILLANUEVA A, et al. A DERL3-associated defect in the degradation of SLC2A1 mediates the Warburg effect $[J]$. Nat Commun ,2014,5:3608. DOI: 10. 1038/ncomms4608.

[31] DÜVEL K, YECIES J L, MENON S, et al. Activation of a metabolic gene regulatory network downstream of mTOR complex 1[J]. Mol Cell, 2010,39(2):171183. DOI: 10. 1016/j. molcel. 2010. 06. 022.

[32] SEMENZA G L. Regulation of cancer cell metabolism by hypoxia-inducible factor $1[\mathrm{~J}]$. Semin Cancer Biol, 2009,19(1):12-16. DOI: 10. 1016/j. semeancer. 2008. 11. 009.

[33] KANG Y H, LEE H S, KIM W H. Promoter methylation and silencing of PTEN in gastric carcino$\mathrm{ma}[\mathrm{J}]$. Lab Invest, 2002,82(3):285-291. DOI : 10. 1038/labinvest. 3780422

[34] VANHARANTA S, SHU W, BRENET F, et al. Epigenetic expansion of VHL-HIF signal output drives multiorgan metastasis in renal cancer $[\mathrm{J}]$. Nat Med, 2013,19(1):50-56. DOI: 10. 1038/nm. 3029.

[35 ] RAWLUSZKO A A, BUJNICKA K E, HORBACKA K, et al. Expression and DNA methylation levels of prolyl hydroxylases PHD1,PHD2,PHD3 and asparaginyl hydroxylase FIH in colorectal cancer $[\mathrm{J}]$. BMC Cancer, 2013,13(1):526. DOI:10. 1186/1471-240713-526.

[36] TROJAN J, BRIEGER A, RAEDLE J, et al. 5'-CpG island methylation of the LKB1/STK11 promoter and allelic loss at chromosome $19 \mathrm{p} 13.3$ in sporadic colorectal cancer $[\mathrm{J}]$. Gut, 2000,47(2):272-276. DOI: 10.1136/gut. 47.2. 272.

[37] XU Y, LIU C, CHEN S, et al. Activation of AMPK and inactivation of Akt result in suppression of mTORmediated S6K1 and 4E-BP1 pathways leading to neuronal cell death in in vitro models of Parkinson's disease $[J]$. Cell Signal, 2014,26(8):1680-1689. DOI: 10. 1016/j. cellsig. 2014. 04. 009.

[38 ] LI H, WANG J, XU H, et al. Decreased fructose-1, 6bisphosphatase-2 expression promotes glycolysis and growth in gastric cancer cells $[\mathrm{J}]$. Mol Cancer, 2013,12(1):110. DOI:10. 1186/1476-4598-12-110.

[39] KOUZARIDES T. Chromatin modifications and their function[J]. Cell, 2007,128(4):693-705. DOI: 10 . 1016/j. cell. 2007. 02. 005.

[40] STRAHL B D, ALLIS C D. The language of covalent histone modifications $[\mathrm{J}]$. Nature, 2000,403(6765): 41-45. DOI: $10.1038 / 47412$.

[41] JENUWEIN T, ALLIS C D. Translating the histone code $[\mathrm{J}]$. Science, 2001,293(5532):1074-1080. DOI : 10. 1126/science. 1063127.

[42] ZHANG Y, REINBERG D. Transcription regulation by histone methylation:interplay between different covalent modifications of the core histone tails $[\mathrm{J}]$. Genes Dev, 2001,15(18):2343-2360. DOI: 10 . $1101 /$ gad. 927301.

[43] MARTIN C, ZHANG Y. The diverse functions of histone lysine methylation[J]. Nat Rev Mol Cell Biol, 2005,6(11) : 838-849. DOI: 10. 1038/nrm1761.

[44] SHILATIFARD A. Chromatin modifications by methylation and ubiquitination:implications in the regulation of gene expression $[J]$. Annu Rev Biochem, 2006,75(1) :243-269. DOI:10. 1146/an- 
nurev. biochem. 75. 103004. 142422.

[45] DORRANCE A M, LIU S, YUAN W, et al. Mll partial tandem duplication induces aberrant Hox expression in vivo via specific epigenetic alterations $[\mathrm{J}]$. J Clin Invest, 2006,116(10):2707-2716. DOI:10. 1172/ jci25546.

[46] SIMON J A, LANGE C A. Roles of the EZH2 histone methyltransferase in cancer epigenetics $[\mathrm{J}]$. Mutat Res/Fundamental Mol Mech Mutagenesis, 2008,647(1-2):21-29. DOI:10. 1016/j. mrfmmm. 2008. 07. 010

[47] MCCABE M T, OTT H M, GANJI G, et al. EZH2 inhibition as a therapeutic strategy for lymphoma with EZH2-activating mutations $[\mathrm{J}]$. Nature, 2012,492 (7427) : 108-112. DOI: 10. 1038/nature11606.

[48] VARAMBALLY S, DHANASEKARAN S M, ZHOU $\mathrm{M}$, et al. The polycomb group protein EZH2 is involved in progression of prostate cancer $[\mathrm{J}]$. Nature, 2002,419(6907):624-629. DOI: 10. 1038/ nature 01075 .

[49] HU H, QIAN K, HO M C, et al. Small molecule inhibitors of protein arginine methyltransferases $[\mathrm{J}]$. Expert Opin Investig Drugs, 2016,25(3):335358. DOI: 10. 1517/13543784. 2016. 1144747.

[50] MATHIOUDAKI K, SCORILAS A, ARDAVANIS A, et al. Clinical evaluation of PRMT1 gene expression in breast cancer $[\mathrm{J}]$. Tumor Biol, 2011,32(3):575582. DOI: 10. 1007/s13277-010-0153-2.

[51] CHEUNG N, FUNG T K, ZEISIG B B, et al. Targeting aberrant epigenetic networks mediated by PRMT1 and KDM4C in acute myeloid leukemia[J]. Cancer Cell, 2016,29(1):32-48. DOI: 10. 1016/j. ccell. 2015. 12. 007.

[52] KOOISTRA S M, HELIN K. Molecular mechanisms and potential functions of histone demethylases $[\mathrm{J}]$. Nat Rev Mol Cell Biol, 2012,13(5):297-311. DOI: $10.1038 / \mathrm{nrm} 3327$.

[53] FENG Z, YAO Y, ZHOU C, et al. Pharmacological inhibition of LSD1 for the treatment of MLL-rearranged leukemia[J]. J Hematol Oncol, 2016,9(1):24. DOI: $10.1186 / \mathrm{s} 13045-016-0252-7$.

[54] VERDIN E, OTT M. 50 years of protein acetylation: from gene regulation to epigenetics, metabolism and beyond $[\mathrm{J}]$. Nat Rev Mol Cell Biol, 2015,16 (4) : 258-264. DOI: 10. 1038/nrm3931.

[55] KOUZARIDES T. Histone acetylases and deacetylases in cell proliferation $[\mathrm{J}]$. Curr Opin Genets Dev, 1999,9(1):40-48. DOI: 10. 1016/s0959-437x (99)80006-9.

[56] WELLEN K E, HATZIVASSILIOU G, SACHDEVA U $\mathrm{M}$, et al. ATP-citrate lyase links cellular metabolism to histone acetylation $[J]$. Science, 2009,324(5930): 1076-1080. DOI:10. 1126/science. 1164097.
[57] KNOEPFLER P S, ZHANG X, CHENG P F, et al. Myc influences global chromatin structure $[\mathrm{J}]$. EMBO J, 2006,25(12) :2723-2734. DOI:10. 1038/ sj. emboj. 7601152.

[58] RICHTERS A, KOEHLER A N. Epigenetic modulation using small molecules - targeting histone acetyltransferases in disease[J]. Curr Med Chem, 2017, 24(37) : 4121-4150. DOI:10. 2174/092986732466 6170223153115

[59] SPANGE S, WAGNER T, HEINZEL T, et al. Acetylation of non-histone proteins modulates cellular signalling at multiple levels $[\mathbf{J}]$. Int $\mathbf{J}$ Biochem Cell Biol, 2009,41(1):185-198. DOI: 10. 1016/j. biocel. 2008. 08. 027.

[60] SEGRÉ C V, CHIOCCA S. Regulating the regulators: the post-translational code of class I HDAC1 and HDAC2 $[J]$. J Biomed Biotech, 2011,2011: 690848. DOI: $10.1155 / 2011 / 690848$.

[61] ZHANG Z G, QIN C Y. Sirt6 suppresses hepatocellular carcinoma cell growth via inhibiting the extracellular signal-regulated kinase signaling pathway $[\mathrm{J}]$. Mol Med Rep, 2014,9(3):882-888. DOI: 10 . 3892/mmr. 2013. 1879.

[62] BARBER M F, MICHISHITA-KIOI E, XI Y, et al. SIRT7 links H3K18 deacetylation to maintenance of oncogenic transformation $[\mathrm{J}]$. Nature, 2012,487 (7405) :114-118. DOI:10. 1038/nature11043.

[63] LIU P Y, XU N, MALYUKOVA A, et al. The histone deacetylase SIRT2 stabilizes Myc oncoproteins[J]. Cell Death Differ, 2013,20(3):503-514. DOI: 10 . 1038/cdd. 2012. 147.

[64] CHEN Y, SPRUNG R, TANG Y, et al. Lysine propionylation and butyrylation are novel post-translational modifications in histones $[\mathrm{J}]$. Mol Cellular Proteomics, 2007,6(5):812-819. DOI:10. 1074/ mcp. M700021-MCP200.

[65] TAN M, LUO H, LEE S, et al. Identification of 67 histone marks and histone lysine crotonylation as a new type of histone modification[J]. Cell, 2011,146 (6) : 1016-1028. DOI: 10. 1016/j. cell. 2011. 08. 008.

[66] XIE Z, DAI J, DAI L, et al. Lysine succinylation and lysine malonylation in histones $[\mathrm{J}]$. Mol Cellular Proteomics, 2012,11(5):100-107. DOI : 10. 1074/ mcp. M111. 015875.

[67] XIE Z, ZHANG D, CHUNG D, et al. Metabolic regulation of gene expression by histone lysine $\beta$ hydroxybutyrylation $[\mathrm{J}]$. Mol Cell, 2016,62(2) : 194206. DOI: 10. 1016/j. molcel. 2016. 03. 036.

[68 ] LEE K K, WORKMAN J L. Histone acetyltransferase complexes : one size doesn't fit all $[J]$. Nat Rev Mol Cell Biol, 2007,8(4):284-295. DOI:10. 1038/ nrm2145.

[69] ROTH S Y, DENU J M, ALLIS C D. Histone 
acetyltransferases $[J]$. Annu Rev Biochem, 2001, 70(1):81-120. DOI:10. 1146/annurev. biochem. 70. 1.81 .

[70] CHENG Z, TANG Y, CHEN Y, et al. Molecular characterization of propionyllysines in non-histone proteins [J]. Mol Cell Proteomics, 2009,8(1) : 4552. DOI: $10.1074 / \mathrm{mcp}$. M800224-MCP200.

[71] KACZMARSKA Z, ORTEGA E, GOUDARZI A, et al. Structure of p300 in complex with acyl-CoA variants [J]. Nat Chem Biol, 2017,13(1):21-29. DOI:10. 1038/nchembio. 2217.

[72] SABARI B R, TANG Z, HUANG H, et al. Intracellular crotonyl-CoA stimulates transcription through p300catalyzed histone crotonylation $[\mathrm{J}]$. Mol Cell, 2015,58 (2) :203-215. DOI : 10. 1016/j. molcel. 2015. 02.029 .

[73] BERNDSEN C E, ALBAUGH B N, TAN S, et al. Catalytic mechanism of a MYST family histone acetyltransferase $[\mathrm{J}]$. Biochemistry, 2007,46(3): 623-629. DOI: 10. 1021/bi602513x.

[74] LEEMHUIS H, PACKMAN L C, NIGHTINGALE K P, et al. The human histone acetyltransferase $\mathrm{P} / \mathrm{CAF}$ is a promiscuous histone propionyltransferase $[\mathrm{J}]$. Chembiochem, 2008,9(4) :499-503. DOI: 10. 1002/ cbic. 200700556.

[75] RINGEL A E, WOLBERGER C. Structural basis for acyl-group discrimination by human Gen5L2[J]. Acta Crystlogr D Struct Biol, 2016,72(7):841848. DOI: $10.1107 / \mathrm{s} 2059798316007907$.

[76] PENG C, LU Z, XIE Z, et al. The first identification oflysine malonylation substrates and its regulatory enzyme $[J]$. Mol Cell Proteomics, 2011,10(12): M111. 012658. DOI: 10. 1074/mcp. M111. 012658.

[77] JIANG G, NGUYEN D, ARCHIN N M, et al. HIV latency is reversed by ACSS2-driven histone crotonylation[J]. J Clin Invest, 2018,128(3 ) : 1190-1198. DOI: $10.1172 /$ jci98071.

[78] MASHIMO T, PICHUMANI K, VEMIREDDY V, et al. Acetate is a bioenergetic substrate for human glioblastoma and brain metastases [J]. Cell, 2014,159 (7): 1603-1614. DOI: 10. 1016/j. cell. 2014. 11.025.

[79] COMERFORD S A, HUANG Z, DU X, et al. Acetate dependence of tumors $[\mathrm{J}]$. Cell, 2014,159(7):15911602. DOI: $10.1016 /$ j. cell. 2014. 11. 020 .

[80] HALLOWS W C, LEE S, DENU J M. Sirtuins deacetylate and activate mammalian acetyl-CoA synthetases $[$ J]. Proc Natl Acad Sci USA, 2006, 103(27):10230-10235. DOI: $10.1073 /$ pnas. 06043 92103.

[81] FELDMAN J L, BAEZA J, DENU J M. Activation of the protein deacetylase SIRT6 by long-chain fatty acids and widespread deacylation by mammalian sirtuins $[$ J]. J Biol Chem, 2013,288(43):31350-
31356. DOI: 10. 1074/jbc. C113. 511261.

[82] TAN M, PENG C, ANDERSON K A, et al. Lysine glutarylation is a protein posttranslational modification regulated by SIRT5[J]. Cell Metab, 2014,19(4): 605-617. DOI: 10. 1016/j. cmet. 2014. 03. 014.

[83] PARK J, CHEN Y, TISHKOFF D X, et al. SIRT5mediated lysine desuccinylation impacts diverse metabolic pathways $[\mathrm{J}]$. Mol Cell, 2013,50(6): 919-930. DOI: 10. 1016/j. molcel. 2013. 06. 001.

[84] DU J, ZHOU Y, SU X, et al. Sirt5 is a NADdependentprotein lysine demalonylase and desuccinylase $[\mathrm{J}]$. Science, 2011,334(6057):806-809. DOI : 10. $1126 /$ science. 1207861.

[85] ALAMOUDI A A, ALNOURY A, GAD H. miRNA in tumour metabolism and why could it be the preferred pathway for energy reprograming $[\mathrm{J}]$. Brief Funct Genomics, 2018,17(3):157-169. DOI:10. 1093/ $\mathrm{bfgp} / \mathrm{elx} 023$.

[86] COHEN A L, HOLMEN S L, COLMAN H. IDH1 and IDH2 mutations in gliomas $[\mathrm{J}]$. Curr Neurol NeuroSci Rep, 2013,13(5):345. DOI:10. 1007/ s11910-013-0345-4.

[87] FIGLIA G, WILLNOW P, TELEMAN A A. Metabolites regulate cell signaling and growth via covalent modification of proteins [J]. Dev Cell, 2020,54(2): 156-170. DOI: 10. 1016/j. devcel. 2020.06. 036.

[88 ] HAN X, XIANG X, YANG H, et al. p300-catalyzed lysine crotonylation promotes the proliferation,invasion, and migration of HeLa cells via heterogeneous nuclear ribonucleoprotein $\mathrm{A} 1[\mathrm{~J}]$. Anal Cellular Pathol, 2020,2020:1-6. DOI:10. 1155/2020/ 5632342.

[89] HUANG H, WANG D L, ZHAO Y. Quantitative crotonylome analysis expands the roles of p300 in the regulation of lysine crotonylation pathway $[\mathrm{J}]$. Proteomics, 2018,18(15):1700230. DOI: 10. 1002/ pmic. 201700230.

[90] LIU J, YUE Y, HAN D, et al. A METTL3-METTL14 complex mediates mammalian nuclear RNA $\mathrm{N}^{6}$ adenosine methylation $[\mathrm{J}]$. Nat Chem Biol, 2014,10 (2) :93-95. DOI: 10. 1038/nchembio. 1432.

[91] PING X L, SUN B F, WANG L, et al. Mammalian WTAP is a regulatory subunit of the RNA $\mathrm{N}^{6}$ methyladenosine methyltransferase $[\mathrm{J}]$. Cell Res, 2014,24(2):177-189. DOI:10. 1038/cr. 2014. 3.

[92] JIA G, FU Y, ZHAO X, et al. $\mathrm{N}^{6}$-Methyladenosine in nuclear RNA is a major substrate of the obesityassociated FTO $[J]$. Nat Chem Biol, 2011,7(12): 885-887. DOI: 10. 1038/nchembio. 687.

[93 ] ZHENG G, DAHL J A, NIU Y, et al. ALKBH5 is a mammalian RNA demethylase that impacts RNA metabolism and mouse fertility $[\mathrm{J}]$. Mol Cell, 2013, 49(1) : 18-29. DOI: 10. 1016/j. molcel. 2012. 10. 015. 
[94] DOMINISSINI D, MOSHITCH-MOSHKOVITZ S, SCHWARTZ S, et al. Topology of the human and mouse m6A RNA methylomes revealed by m6A-seq [J]. Nature, 2012,485(7397):201-206. DOI: 10 . 1038/nature11112.

[95] WANG X, LU Z, GOMEZ A, et al. N'-methyladenosine-dependent regulation of messenger RNA stability [J]. Nature, 2014,505(7481):117-120. DOI: 10 . 1038/nature12730.

[96] WANG X, ZHAO B S, ROUNDTREE I A, et al. $\mathrm{N}^{6}$ methyladenosine modulates messenger RNA translation efficiency[J]. Cell, 2015,161(6): 1388-1399. DOI: 10. 1016/j. cell. 2015. 05. 014.

[97] XIAO W, ADHIKARI S, DAHAL U, et al. Nuclear $\mathrm{m}^{6}$ a reader YTHDC1 regulates mRNA splicing $[\mathrm{J}]$. Mol Cell, 2016,61(4):507-519. DOI: 10. 1016/j. molcel. 2016. 01. 012.

[98 ] LI Z, WENG H, SU R, et al. FTO plays an oncogenicrole in acute myeloid leukemia as a $\mathrm{N}^{6}$-methyladenosine RNA demethylase $[\mathrm{J}]$. Cancer Cell, 2017,31 (1): 127-141. DOI: 10. 1016/j. ccell. 2016. 11. 017.

[99] ZHANG S, ZHAO B S, ZHOU A, et al. $\mathrm{M}^{6}$ a demethylase alkbh5 maintains tumorigenicity of glioblastoma stem-like cells by sustaining FOXM1 expression and cell proliferation program $[\mathrm{J}]$. Cancer Cell, 2017,31(4):591-606. e6. DOI: 10. 1016/j. ccell. 2017. 02. 013.

[100 ] TANABE A, TANIKAWA K, TSUNETOMI M, et al. RNA helicase YTHDC2 promotes cancer metastasis via the enhancement of the efficiency by which HIF$1 \alpha$ mRNA is translated [J]. Cancer Lett, 2016,376 (1):34-42. DOI: 10. 1016/j. canlet. 2016. 02. 022.

[101] SU R, DONG L, LI C, et al. R-2HG exhibits antitumor activity by targeting $\mathrm{FTO} / \mathrm{m} 6 \mathrm{~A} / \mathrm{MYC} / \mathrm{CEBPA}$ signaling $[\mathrm{J}]$. Cell, 2018,172(1-2):90-105. e23. DOI : 10. 1016/j. cell. 2017. 11. 031.

[102] CUI Q, SHI H, YE P, et al. m ${ }^{6}$ a RNA methylation regulates the self-renewal and tumorigenesis of glioblastoma stem cells $[\mathrm{J}]$. Cell Rep, 2017,18 (11):2622-2634. DOI:10. 1016/j. celrep. 2017. 02.059 .

[103] LIU J, ECKERT M A, HARADA B T, et al. m6A mRNA methylation regulates AKT activity to promote the proliferation and tumorigenicity of endometrial cancer $[J]$. Nat Cell Biol, 2018,20(9) : 1074-1083. DOI : 10. 1038/s41556-018-0174-4.

[104] ALARCÓN C R, LEE H, GOODARZI H, et al. $\mathrm{N}^{6}$ methyladenosine marks primary microRNAs for processing $[J]$. Nature, 2015,519(7544):482485. DOI: $10.1038 /$ nature 14281 .

[105] ZHOU C, MOLINIE B, DANESHVAR K, et al. Genome-wide maps of m6a circrnas identify widespread and cell-type-specific methylation patterns that are distinct from mRNAs $[\mathrm{J}]$. Cell Rep, 2017,20 (9):2262-2276. DOI : 10. 1016/j. celrep. 2017. 08.027.

[106] ZHOU K I, PARISIEN M, DAI Q, et al. $\mathrm{N}^{6}$ methyladenosine modification in a long noncoding rna hairpin predisposes its conformation to protein binding $[\mathrm{J}]$. J Mol Biol, 2016,428(5):822-833. DOI: 10. 1016/j. jmb. 2015. 08. 021.

[107] WEI J W, HUANG K, YANG C, et al. Non-coding RNAs as regulators in epigenetics $[\mathrm{J}]$. Oncology Rep, 2017,37(1):3-9. DOI: 10. 3892/or. 2016. 5236.

[108] BARTEL D P. MicroRNAs : target recognition and regulatory functions $[\mathrm{J}]$. Cell, 2009,136(2):215233. DOI: 10. 1016/j. cell. 2009. 01.002.

[109] MACHEDA M L, ROGERS S, BEST J D. Molecular and cellular regulation of glucose transporter (GLUT) proteins in cancer[J]. J Cell Physiol, 2005,202 (3) :654-662. DOI: 10. 1002/jcp. 20166.

[110] CHEN B, TANG H, LIU X, et al. miR-22 as a prognostic factor targets glucose transporter protein type 1 in breast cancer $[\mathrm{J}]$. Cancer Lett, 2015,356 (2) :410-417. DOI:10. 1016/j. canlet. 2014. 09. 028 .

[111] YAMASAKI T, SEKI N, YOSHINO H, et al. Tumorsuppressive microRNA-1291 directly regulates glucose transporter 1 in renal cell carcinoma $[\mathrm{J}]$. Cancer Sci, 2013,104(11) :1411-1419. DOI: 10 . $1111 /$ cas. 12240.

[112] FEI X, QI M, WU B, et al. MicroRNA-195-5p suppresses glucose uptake and proliferation of human bladder cancer T24 cells by regulating GLUT3 expression $[J]$. FEBS Lett, 2012,586(4):392397. DOI: 10. 1016/j. febslet. 2012. 01. 006.

[113] GREGERSEN L H, JACOBSEN A, FRANKEL L B, et al. MicroRNA-143 down-regulates hexokinase 2 in colon cancer cells $[\mathrm{J}]$. BMC Cancer, 2012,12 (1) :232. DOI: 10. 1186/1471-2407-12-232.

[114] SONG J, WU X, LIU F, et al. Long non-coding RNAPVT1 promotes glycolysis and tumor progression by regulating miR-497/HK2 axis in osteosarcoma [J]. Biochem BioPhys Res Commun, 2017, 490 (2) : 217-224. DOI: 10. 1016/j. bbrc. 2017. 06. 024.

[115] TSAI W C, HSU P W C, LAI T C, et al. MicroRNA122 , a tumor suppressor microRNA that regulates intrahepatic metastasis of hepatocellular carcinoma $[\mathrm{J}]$. Hepatology, 2009,49(5):1571-1582. DOI: 10 . 1002/hep. 22806.

[116] LI Y, KONG D, AHMAD A, et al. Epigenetic deregulation of miR-29a and miR-1256 by isoflavone contributes to the inhibition of prostate cancer cell growth and invasion[J]. Epigenetics, 2012,7(8): 940-949. DOI: 10. 4161/epi. 21236. 
[117] KEFAS B, COMEAU L, ERDLE N, et al. Pyruvate kinase M2 is a target of the tumor-suppressive microRNA-326 and regulates the survival of glioma cells $[J]$. Neuro-Oncology, 2010,12(11) : 11021112. DOI: $10.1093 /$ neuonc/noq080.

[118] LIU A M, XU Z, SHEK F H, et al. miR-122 targets pyruvate kinase $\mathrm{M} 2$ and affects metabolism of hepatocellular carcinoma[J/OL]. PLoS One, 2014, 9(1) : e86872. DOI : 10. 1371/journal. pone. 0086872.

[119] TANIGUCHI K, SUGITO N, KUMAZAKI M, et al. MicroRNA-124 inhibits cancer cell growth through PTB1/PKM1/PKM2 feedback cascade in colorectal cancer $[J]$. Cancer Lett, 2015,363(1):17-27. DOI: 10. 1016/j. canlet. 2015. 03. 026.

[120] WANG J, WANG H, LIU A, et al. Lactate dehydrogenase A negatively regulated by miRNAs promotes aerobic glycolysis and is increased in colorectal cancer $[\mathrm{J}]$. Oncotarget, 2015,6(23): 19456-19468. DOI : 10. 18632/oncotarget. 3318.

[121] LIU L, WANG Y, BAI R, et al. MiR-186 inhibited aerobic glycolysis in gastric cancer via HIF-1 $\alpha$ regulation $[\mathrm{J} / \mathrm{OL}]$. Oncogenesis, 2016,5(5) : e224. DOI: 10. 1038/oncsis. 2016. 35.

[122] TAKAHASHI K, YAN I K, HAGA $\mathrm{H}$, et al. Modulation of hypoxia-signaling pathways by extracellular linc-RoR[J]. J Cell Sci, 2014,127(7): 1585-1594. DOI: 10. 1242/jcs. 141069.

[123] CHEN Z, ZENG H, GUO Y, et al. miRNA-145 inhibits non-small cell lung cancer cell proliferation by targeting c-Myc $[\mathrm{J}]$. J Exp Clin Cancer Res, 2010,29(1): 151. DOI: 10. 1186/1756-9966-29-151.

[124] YAMAMURA S, SAINI S, MAJID S, et al. MicroRNA-34a modulates c-Myc transcriptional complexes to suppress malignancy in human prostate cancer cells[J/OL]. PLoS One, 2012,7(1): e29722. DOI: $10.1371 /$ journal. pone. 0029722 .

[125] TSAI W C, HSU S D, HSU C S, et al. MicroRNA-122 plays a critical role in liver homeostasis and hepatocarcinogenesis [J]. J Clin Invest, 2012,122 (8) : 2884-2897. DOI:10. 1172/jci63455.

[126] HE J, ZHAO K, ZHENG L, et al. Upregulation of microRNA-122 by farnesoid X receptor suppresses the growth of hepatocellular carcinoma cells $[\mathrm{J}]$. Mol Cancer, 2015,14(1) : 163. DOI: 10. 1186/s12943015-0427-9.

[127] ESAU C, DAVIS S, MURRAY S F, et al. miR-122 regulation of lipid metabolism revealed by in vivo antisense targeting $[\mathrm{J}]$. Cell Metab, 2006,3(2) :8798. DOI : 10. 1016/j. cmet. 2006. 01.005.

[128 ] CUI M, WANG Y, SUN B, et al. MiR-205 modulatesabnormal lipid metabolism of hepatoma cells via targeting acyl-CoA synthetase long-chain family member 1 (ACSL1) mRNA $[\mathrm{J}]$. Biochem BioPhys Res Commun, 2014,444(2):270-275. DOI: 10 . 1016/j. bbrc. 2014. 01.051.

[129] NOGUCHI S, IWASAKI J, KUMAZAKI M, et al. Chemically modified synthetic microRNA-205 inhibits the growth of melanoma cells in vitro and in vivo [J]. Mol Ther, 2013,21(6) : 1204-1211. DOI: 10. 1038/mt. 2013. 70.

[130] PHANG J M, LIU W, HANCOCK C N, et al. Proline metabolism and cancer $[\mathrm{J}]$. Curr Opin Clin Nutrition Metabolic Care, 2015,18(1):71-77. DOI: $10.1097 / \mathrm{mco} .0000000000000121$.

[131] GAO P, TCHERNYSHYOV I, CHANG T C, et al. c-Myc suppression of miR-23a/b enhances mitochondrial glutaminase expression and glutamine metabo$\operatorname{lism}[\mathrm{J}]$. Nature, 2009,458(7239) : 762-765. DOI : 10. 1038/nature07823.

[132] LIU W, LE A, HANCOCK C, et al. Reprogramming of proline and glutamine metabolism contributes to the proliferative and metabolic responses regulated by oncogenic transcription factor c-MYC $[J]$. Proc Natl Acad Sci USA, 2012,109(23):8983-8988. DOI : 10. 1073 /pnas. 1203244109.

[133] JECK W R, SHARPLESS N E. Detecting and characterizing circular RNAs $[\mathrm{J}]$. Nat Biotechnol, 2014,32(5):453-461. DOI: 10. 1038/nbt. 2890.

[134] HANSEN T B, JENSEN T I, CLAUSEN B H, et al. Natural RNA circles function as efficient microRNA sponges $[\mathrm{J}]$. Nature, 2013,495(7441):384-388. DOI: $10.1038 /$ nature11993.

[135] STOLL L, SOBEL J, RODRIGUEZ-TREJO A, et al. Circular RNAs as novel regulators of $\beta$-cell functions in normal and disease conditions $[\mathrm{J}]$. Mol Metab, 2018,9:69-83. DOI:10. 1016/j. molmet. 2018. 01.010.

[136] ZHENG Q, BAO C, GUO W, et al. Circular RNA profiling reveals an abundant circHIPK3 that regulates cell growth by sponging multiple miRNAs $[\mathrm{J}]$. Nat Commun, 2016,7(1):11215. DOI:10.1038/ ncomms11215.

[137] LIANG G, LIU Z, TAN L, et al. HIF1 $\alpha$-associatedcircDENND4C promotes proliferation of breast cancer cells in hypoxic environment $[\mathrm{J}]$. Anticancer Res, 2017,37(8):4337-4343. DOI: 10. 21873/anticanres. 11827.

[138] DANG R Y, LIU F L, LI Y. Circular RNA hsa_circ_ 0010729 regulates vascular endothelial cell proliferation and apoptosis by targeting the miR-186/HIF$1 \alpha \operatorname{axis}[\mathrm{J}]$. Biochem BioPhys Res Commun, 2017,490(2) : 104-110. DOI: 10. 1016/j. bbrc. 2017. 05. 164.

[139] XIE H, REN X, XIN S, et al. Emerging roles of circRNA_001569 targeting miR-145 in the prolifera- 
tion and invasion of colorectal cancer $[\mathrm{J}]$. Oncotarget, 2016,7(18):26680-26691. DOI:10. 18632/oncotarget. 8589.

[140 ] YU C Y, LI T C, WU Y Y, et al. The circular RNA circBIRC6 participates in the molecular circuitry controlling human pluripotency $[\mathrm{J}]$. Nat Commun, 2017,8(1) : 1149. DOI : 10. 1038/s41467-017-01216-w.

[141] ULITSKY I, BARTEL D P. lincRNAs:genomics, evolution, and mechanisms [J]. Cell, 2013,154(1): 26-46. DOI: 10. 1016/j. cell. 2013. 06. 020.

[142] ZOU Z W, MA C, MEDORO L, et al. LncRNA ANRIL is up-regulated in nasopharyngeal carcinoma and promotes the cancer progression via increasing proliferation,reprograming cell glucose metabolism and inducing side-population stem-like cancer cells [J]. Oncotarget, 2016,7(38):61741-61754. DOI:10. 18632/oncotarget. 11437.

[143] WEI S, FAN Q, YANG L, et al. Promotion of glycolysis by HOTAIR through GLUT1 upregulation via mTOR signaling $[\mathrm{J}]$. Oncology Rep, 2017,38 (3) : 1902-1908. DOI: 10.3892/or. 2017. 5840.

[144] ZHAO Y, LIU Y, LIN L, et al. The lncRNA MACC1AS1 promotes gastric cancer cell metabolic plasticity via AMPK/Lin28 mediated mRNA stability of MACC1 $[J]$. Mol Cancer, 2018,17(1):69. DOI : 10. 1186/s12943-018-0820-2.

[145] LI H, LI J, JIA S, et al. miR675 upregulates long noncoding RNA H19 through activating EGR1 in human liver cancer $[\mathrm{J}]$. Oncotarget, 2015,6(31): 31958-31984. DOI:10. 18632/oncotarget. 5579.

[146] MA M Z, ZHANG Y, WENG M Z, et al. Long noncoding RNA GCASPC, a target of miR-17-3p, negatively regulates pyruvate carboxylase-dependent cell proliferation in gallbladder cancer $[\mathrm{J}]$. Cancer Res, 2016,76(18):5361-5371. DOI:10. 1158/ 0008-5472. Can-15-3047.

[147] NGUYEN H B, BABCOCK J T, WELLS C D, et al. LKB1 tumor suppressor regulates AMP kinase/ mTOR-independent cell growth and proliferation via the phosphorylation of Yap $[\mathrm{J}]$. Oncogene, 2013,32 (35) : 4100-4109. DOI:10. 1038/onc. 2012. 431.

[148] CHEN Z, LI J L, LIN S, et al. cAMP/CREBregulated LINC00473 marks LKB1-inactivated lung cancer and mediates tumor growth $[\mathrm{J}]$. J Clin Invest, 2016,126(6):2267-2279. DOI: 10. 1172/ jci85250.

[149] LIU X, XIAO Z D, HAN L, et al. LncRNA NBR2 engages a metabolic checkpoint by regulating AMPK under energy stress[J]. Nat Cell Biol, 2016,18
(4) : 431-442. DOI: 10. 1038/ncb3328.

[150] YANG F, ZHANG H, MEI Y, et al. Reciprocal regulation of HIF-1 $\alpha$ and lincRNA-p21 modulates the Warburg effect[J]. Mol Cell, 2014,53(1) : 88100. DOI: 10. 1016/j. molcel. 2013. 11. 004.

[151] LUO F, LIU X, LING M, et al. The lncRNA MALAT1, acting through HIF-1 $\alpha$ stabilization, enhances arsenite-induced glycolysis in human hepatic L-02 cells $[\mathrm{J}]$. BioChim Biophysica Acta (BBA) Mol Basis Dis, 2016,1862(9):1685-1695. DOI: 10. 1016/j. bbadis. 2016. 06. 004.

[152] WU W, HU Q, NIE E, et al. Hypoxia induces H19 expression through direct and indirect Hif-1 $\alpha$ activity, promoting oncogenic effects in glioblastoma [J]. Sci Rep, 2017,7(1):45029. DOI : 10. 1038/ srep45029.

[153] LIN A, LI C, XING Z, et al. The LINK-A lncRNA activates normoxic HIF1 $\alpha$ signalling in triplenegative breast cancer[J]. Nat Cell Biol, 2016,18 (2) :213-224. DOI: 10. 1038/ncb3295.

[154] MADDOCKS O D K, VOUSDEN K H. Metabolic regulation by $\mathrm{p} 53[\mathrm{~J}]$. J Mol Med, 2011,89(3): 237-245. DOI:10. 1007/s00109-011-0735-5.

[155] WU M, AN J, ZHENG Q, et al. Double mutant P53 (N340Q/L344R) promotes hepatocarcinogenesis through upregulation of Pim1 mediated by PKM2 and LncRNA CUDR $[J]$. Oncotarget, 2016,7(41): 66525-66539. DOI:10. 18632/oncotarget. 9089.

[156] ZHOU Y, ZHONG Y, WANG Y, et al. Activation of p53 by MEG3 non-coding RNA[J]. J Biol Chem, 2007,282(34):24731-24742. DOI : 10. 1074/jbc. M702029200.

[157] MAHMOUDI S, HENRIKSSON S, CORCORAN M, et al. Wrap53, a natural p53 antisense transcript required for p53 induction upon DNA damage $[\mathrm{J}]$. Mol Cell, 2009,33(4) :462-471. DOI: 10. 1016/j. molcel. 2009. 01. 028.

[158] TRIPATHI V, SHEN Z, CHAKRABORTY A, et al. Long noncoding RNA MALAT1 controls cell cycle progression by regulating the expression of oncogenic transcription factor B-MYB $[\mathrm{J} / \mathrm{OL}]$. PLoS Genet, 2013,9(3) : e1003368. DOI: 10. 1371/journal. pgen. 1003368.

[159] ZHANG A, ZHOU N, HUANG J, et al. The human long non-coding RNA-RoR is a p53 repressor in response to DNA damage[J]. Cell Res, 2013,23 (3) :340-350. DOI: 10. 1038/cr. 2012. 164.

[本文编辑 沈 敏 余 方] 